\title{
Analysis on the Application of National Elements in the Modern Art Design
}

\author{
Yiling Tang \\ Art Design College, Hunan International Economics University, Changsha, 410205, China
}

Keywords: National elements, Modern art design, Application analysis, National pattern and symbol, Color

\begin{abstract}
Five thousand years' cultural inheritance accumulated the special "national elements” of China. Our country's "national elements" are used widely into many fields of modern art designs of both Eastern and Western countries. It shows China's special cultural connotation and history. In this paper, the author firstly explains two concepts of "national elements" and "modern art designs", and based on these two concepts to analyze the art characters of "national elements" in the modern art design to explore the application principle and method of "national elements" in the modern art design.
\end{abstract}

\section{Introduction}

National elements have a close relationship with national culture, national elements express national culture, national culture consists of many different national elements. At present, designer in different industries and different fields pay more and more attention to national elements. Therefore, national elements of different nations have already become a hot topic in the modern art design. Our national elements manifest our national consciousness and characters, and have an incalculable influence. Now, national elements are expressing by the forms of architecture, paper-cut, embroidery and wash painting in the modern art design.

\section{Connotation of "national elements" and "modern art design"}

National elements is the sublimation of the culture of one nation, is the expression of the nation character, therefore, it becomes the symbol of our national culture and spirit. National elements are expressed in different patterns, different colors and different structures, showing our nation sentiment wish for happy life. Set modern family property industry as an example, cheongsam, as a traditional dress in our country, is the typical representative of our national dress. When integrated with many modern elements, like high-heeled shoes, lesbine underwear and silk stocks, cheongsam will increase fashion in the classical and tradition. The high-ranking dressing design with national elements also becomes an important expression of our deep national culture. Line is an important language in art design, with unique art charm. Thickness, length, shape, weight and dense of different lines can not only express the feeling of quality, trends, space, volume, direction, even can express out speed and strength. Therefore, the Chinese painting can realize "ask for its spirit and see its life". These all are important expression of Chinese culture quintessence. For modern art design, using national elements means not only learn how to use lines, but also grasp the development speed and level of modern art design. Besides, also need to know the acceptance and understanding ability of the public, develop in the heritance, innovate in the development to make Chinese art go abroad and glory in the worldwide.

Deep understanding and exploration of the national element are needed for its reasonable and flexible application in modern art design. National elements normally include pictures and tattoos (includes human, animal and plant, tattoos pictures) with national typical characters and connotations, and some allusions, myth and legends that familiar to people. While art design is a visible creative activity expressed by the designer in a form after he deeply understood something and combined his thoughts and purpose. Application of national element in the art design requires the designer to have a thorough understanding on the style, meaning, connotation of the national element, and combine it with religion culture and beauty appreciation psychology to create an art work with sense of beauty. 
Application of national element in the modern art design can enhance charm of the art work as well as broadcast our national culture to the world, strengthen national confidence and carry forward our national culture.

\section{Art characters of national elements in the modern art design}

\section{Aesthetics is the first character of national element when used in the modern art design}

At present, many designs can be called art design is because these art designs have unique charm and aesthetics. Art design asks for aesthetics, this is quite complied with the connotation of national elements. Actually, national element is a wish and expression for beautiful things, for example, the Chinese knot represents unit and friendship, auspicious clouds represents richness, honor and lucky. They not only expressed people's wish for good life, but also have a beautiful appearance. Most of the Chinese national elements are like this, with an inner beauty as well as an appearance beauty. Therefore, both appearance beauty and inner beauty of the national elements should be considered when used in the modern art design. Based on this to enrich the aesthetics of art design, to make it more vivid and refine. Besides that, it also can make the style of the modern art design with more connotation and higher spirit.

\section{Uniqueness of national element in the modern art design}

For a brilliant nation, its national culture should have two features, one is the uniqueness, the other is its generality with the world. These two features make the national elements have nation uniqueness in the modern art design. Therefore, when use national element in the modern art design, must seize these two characters to make the art design both with generality and individuality to show the charm of our national culture. Until now, there are more and more typical Chinese elements are used into different fields of modern art design. Add national elements in modern art design to make it express different charm and become the art work with traditional culture quintessence and national culture features. Besides, using national elements in the modern art design can also integrate the unique thinking way and beauty appreciation with the design concept to show people's value and spirit in the modern society.

\section{Application principle of national element in the modern art design}

Key of applying national element is to ask the designer to blend it perfectly into the modern art design. For example, applying national element into furniture design needs to consider beauty with practical and function. In the design of modern architecture, after applying national elements, it still needs to consider the quality, practical, eco-friendly and economic first. Though there are many perfect works of Chinese traditional art design, but also with some defects, for example, symmetrical layout is the main method for layout, it has stable forms, deep color is the main color, materials are mainly wood and stone, all these will easy to bring people the feeling of old, depress and sameness. Obviously, this is not the demand of modern art designs. Thus traditional elements must make some change for its perfect application in modern art design.

Make some change based on the symmetrical and balance form to make the space form more abundant. For colors, through contrast between bright and dark to make the whole space have feeling of layering. For materials, pay more attention to the application of glass, stainless steel, plastic and other modern materials to guarantee the Chinese character in the architecture and looks more fashion and modern. In the French architect-Bei Jinming's extension project of the famous treasure house Louvre, modern material was used to build a glass pyramid in the Napoleon courtyard in the Louvre. No matter designers in the same field or common people, most of them are with objections for this design. While after this pyramid was finished, it became "a huge gem flying into Louvre" for it composed a beautiful landscape with seven triangle spray ponds. 


\section{Color collocation of national element design}

In modern art design, if one wants to use national elements ingeniously, he should pay attention to the color collocation.

Designers must understand the connotation of each color. Black represents steady nad rigorous, it has stable visual effect; while yellow represents power and noble; golden yellow represents richness and power; red represents passion and prosperous.

These colors are the national elements color, their reasonable application can not only make whole picture or space very harmonious, but also be complement with modern aesthetics.

This is best expressed in Beijing Xiangshan Hotel. Colors of Xiangshan Hotel are color elements in the Jiangnan regional architecture, only three colors make the whole space very harmonious.

White is the main color of Xiangshan Hotel, the entire wall includes outer and interior wall are all white.

While gray is the middle color, used on the places like frame of door and window, window lattice and roof.

While the third color-yellowish-brown is just used on the bedding, carpet, office desk and chairs.

\section{Patterns and symbols of national element design}

Applying national elements into modern art design should pay attention to the value and function of traditional national patterns, because these patterns are the wisdom crystallization of the mass of working people, are peoples wish for happy life, are the base and source of art and crafts design, are the essence, are the symbol of Chinese nation, and they can be widely used into the design of traditional Chinese painting, fitment decorate, china and traditional dresses. Chinese traditional patterns are mainly used to express good morals like good luck, safeness, more sons more blessings and luck-wealth-long live-happiness. For example, the patterns of dragon, phoenix, Kylin, lion and tigers, are mostly used to guard house for the solemn of their appearance. While the four gentleman-plum blossom, orchid, bamboo and chrysanthemum, which are deeply loved by refined scholars, are synonym of noble character in the poets and essays. The most common patterns in China are bat, deer, fish, pomegranate, mandarin duck, pine crane and so on.

Patterns are widely used in different fields for their function of information transition. Patters become a very important part in the advertisement logo design for the features of symbolization and visualization, and there are many typical representatives. Set the symbol design of Hua Xia Bank as an example, jade dragon of the Neolithic age as its appearance, makes it visualized and more simple. Besides, shape of the symbol likes the ancient coin, ingeniously combine ancient time with modern, China and Bank. Space on the right and the dragon tail express the good wish for rising rapidly of Hua Xia Bank.

\section{Ways for the application of national elements in modern art design \\ Blending modern art forms to inherit and develop national elements}

As the aesthetic concept accumulated through a long period's development of a nation, national elements cannot be used in to modern art design without changes, but should be inherited and developed based on the combination with development character and aesthetic concept of the new age. Development of culture, science and technology are two main factors that influence modern aesthetics, it also has important influence on the application of national elements in modern art design. Application of national elements in modern art design needs to pay attention to the design concept of humanization and ecologicalization to make the art design "healthy, comfortable and beautiful" to comply with the development demand of modern art design. Art design with traditional national elements needs to pay attention to innovation and development, needs to express with modern, fashionable and new forms under the premise that considering the aesthetics acceptance ability of modern public. And take "people-oriented" as the first principle at the same time. 


\section{Development and innovation based on modern aesthetics concept}

The key point of the application of national elements in modern art design is to develop and innovate with the aesthetics concept. Therefore, national elements should be inherited and innovated on the basis of national culture inheritance, to realize "make the past serve the present, make foreign things serve China". Application of national elements is to make art design with national characteristics, to express Chinese manner, thus, national elements cannot be applied mechanically. Just as the modern famous art designer-Mr. Jin Diqiang said "Chinese designers prefer to use Chinese symbols, this is normal and no problems, but I hope this is not an apparent copy and imitation, and with real thinking. These elements should change into your own language with your thinking." Another famous designer in China-Mr. Chen Shaohua also said "What is the tradition of Chinese plane designing? I think it not just mean the Chinese patterns passed for thousands of years, but mainly means the Chinese nation characteristics in the plane designing, also means the thinking way and cultural precipitation of Chinese people.” This requires modern designers not just apply national elements mechanically, or just imitate simply, but to have a deep understanding on these national elements. Deeply grasp the aesthetics sense for national elements, develop and innovate on the basis of modern aesthetics concept, only in this way, the design works can emit the charm of national elements from inside to outside, also only in this way, can be the representative works of our country and nation, can go abroad to express Chinese culture essence.

\section{References}

[1] Tao Xiongjun. Thoughts on the Integration of National Elements with Design Teaching.. China high technology enterprises. 2007(10): 200-203.

[2] Huang Kai. Real Value of National Environmental Design. Journal of Huainan Normal University. 2003(02): 25-26.

[3] Yu Qilin, Xiao Junhua. Application of National Elements in the Teaching of Modern Interior Design.. Shanghai Artists. 2010(04): 78-80.

[4] Yang Lei. Analysis on the Application of Traditional Decoration Elements in the Interior Design.. Journal of Changchun College of Education. 2009(02): 138-139.

[5] Gu Yan. Chinese National Elements and Art Design Teaching.. Research on Education Practice. 2009(25): 219-224. 